\title{
CONTAINER PORT EXPANSION TOWARDS THE SEA IN THE CONTEXT OF MARITIME SPATIAL PLANNING
}

\section{Karolina A. Krośnicka}

Faculty of Architecture, Gdańsk University of Technology

Narutowicza 11/12, 80-233 Gdańsk: Poland

karolina.krosnicka@pg.edu.pl

\begin{abstract}
The growth in the size of ships causes, in particular, a significant increase in demand for port surfaces and for the depths of water areas needed to serve ships in the ports. Due to technological changes in the transshipment and storage systems, and, on the other hand, due to the continuing pressure of developing cities, ports have increasingly rarely the adequate space reserves for their activities, and so currently they move towards the sea with their activities. The paper discusses the reasons for the phenomenon of expansion of ports towards the sea and its effects on maritime spatial planning.
\end{abstract}

Keywords: maritime spatial planning, port evolution, seaports.

\section{Introduction}

Investment projects within the maritime areas are still growing: new offshore cables and pipelines are being laid in the sea areas, mining platforms are built, complexes of wind farms and aqua-culture farms are erected, leisure and tourist activities are being developed, etc. These activities have important consequences for both the sea and the land areas and very often they affect negatively the natural habitats. Hence, it became necessary to define the rules for using maritime areas, and thus to develop maritime spatial planning (MSP) and coordinate these activities at the interface between sea and land areas. Among the objects expanding towards the sea area are ports, which should therefore be the subject of marine area planning (Zaucha \& Matczak, 2018). Their spatial evolution proceeds simultaneously towards land and sea, increasingly shifting transshipment and storage activities to newly-reclaimed areas created in sea basins. The article discusses the causes behind the phenomenon of expansion of sea ports towards the sea and its effects on maritime planning.

\section{What is a seaport today?}

A seaport consists of land (port territory) and water areas. So far, spatial planning of havens has been mainly implemented from the point of view of the territory and its transport links with the mainland. From the point of view of efficiency of the cargo flow through the port, trans- 
port accessibility from the water side is at least an equally important issue. It is often forgotten how extensive and important for the efficient functioning of the port are water areas, including, in particular, external waters, located outside breakwaters, such as approach channels or anchorage areas, performing extremely important functions for the port. The vessels wait there for permission of the master's office to enter the port, pilots, customs clearance, provisioning (supply of water and food), and for phytosanitary inspections. Actions such as pest control, fumigation and firefighting are carried out here. Another important function of the anchorage area from the point of view of the port's operation is partial unloading and partial loading of the ships. This activity results from the increase in ships draft and the lack of adequate depth in internal port waters (basins and port channels). Growing ship sizes (e.g. the largest MSC Gülsün container ship of 2019 with load capacity of 23.756 TEU has the length of $399.9 \mathrm{~m}$ and a width of $61.55 \mathrm{~m}$ ) mean that the surface of anchorage area is currently expanding significantly. Anchorages are located at a distance from the port (usually about a couple of nautical miles from the port entrance). They are divided into zones intended for ships belonging to different size and cargo groups and are characterized by quite large natural depths. Anchoring vessel takes not only the surface of their position up to the depth of immersion of the unit, but also the water space between the bottom of water basin and the vessel's keel, in which the anchor chain positioning the vessel extends.

The territory of the port is composed of several zones, extending approximately parallel to the quays - the operating zone located directly above the water, the direct backroom, and the general-port zone (Krośnicka, 2014). The operational area consists of a number of transshipment terminals, each of which forms a port subsystem. Port terminals are equipped with transport infrastructure and storage areas, adequate to the cargo they handle (general cargo, containers, ro-ro, bulk, fuel, etc.). In the face of ever-increasing parameters of vessels and the growing volume of cargo transported to and from the port, not only the transshipment and storage areas of the terminal itself are growing (Fig. 1), but also the surface of other zones, including, in particular, the direct facilities (including access infrastructure to the terminal and logistics and technical support).

In the face of technological change in the transshipment and storage systems, most of the existing seaports do not have land reserves of needed size, which is often the result of an urban pressure, with housing or service buildings approaching the port. Facing the absence of areas for development in the immediate vicinity, ports are seeking for new solutions: next to optimization or automation of their activities they try to expand into the direction of hinterland or to create new surfaces by land reclamation (expansion towards the sea). The second group of actions must be accounted for in maritime spatial development plans. 

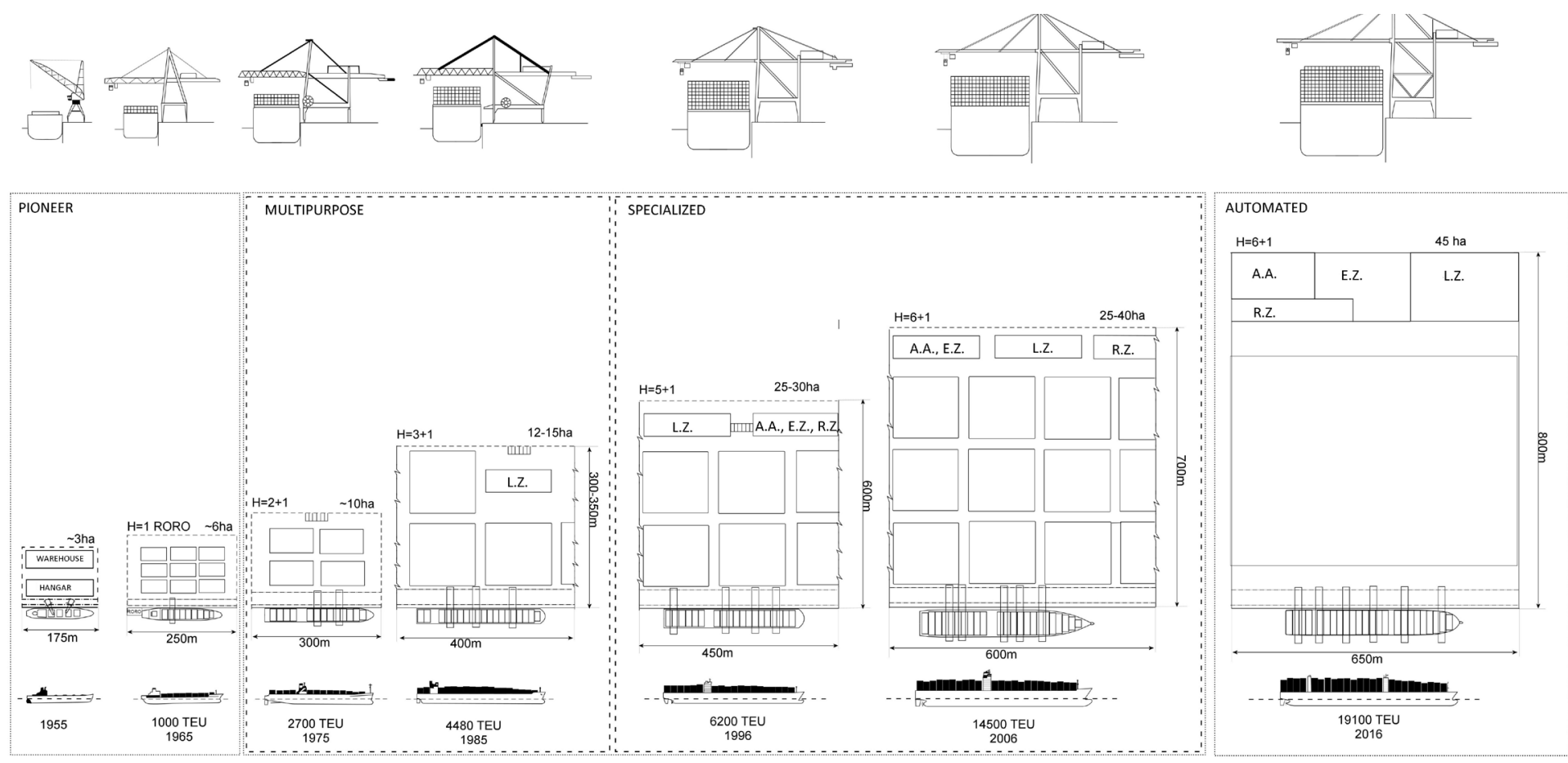

Figure 1. Model of changes in the spatial structure of container terminals within their borders in terms of threshold analysis in the period 1956-2016 Upper line: cross-section through the container berth in particular periods, middle line: container vessel mooring place with the related storage and transportation area seen from above, lower line: cross-sections through the biggest container vessel in consecutive periods; A.A. - administrative area, E.Z. - entry zone, H number of container tiers in a block, L.Z. - logistic zone, R.Z. - railway zone Source: Krośnicka (2016, p.53). 


\section{Port expansion towards the land}

As a result of providing roads system and technical infrastructure for areas dedicated to the port function, new investment opportunities usually open up in their surroundings. For this reason, the spatial development of cities and port agglomerations often leads to urbanization of the areas surrounding the port, sometimes even of port land reserves. For housing and service functions, the vicinity of the emerging transport and logistics developments of the port is usually burdensome. Hence, usually, the new residents do not have a positive attitude towards the new port and logistic projects, although they were planned in a given area. It also happens that the port area borders with extremely valuable natural areas, which are covered by various forms of protection and it is not possible to expand the port into such neighboring areas. In addition, growing technological requirements often go beyond planners' expectations of the available land reserves. Due to the lack of sufficiently extensive land reserves for port development, resulting from the above reasons, a spatial dispersion of functional port elements within the port hinterland is observed.

This phenomenon is called Standortsplittung (Schätzl, 1996). Spatial de-concentration of terminals (this applies particularly to container and general cargo terminals) takes place at different distances from the port and can currently apply to a whole range of port functions (Fig. 2). The external elements of terminals are grouped in the following zones: in the vicinity of the main part of the port (up to $5 \mathrm{~km}$ from the maritime container terminal), within the port metropolis (up to $50 \mathrm{~km}$ ), in the port metropolitan region (from 150 to $300 \mathrm{~km}$ ), within a further hinterland of the port (beyond $300 \mathrm{~km}$ ). Functions implemented in particular zones include, among others: technical facilities, service for external transport (rail and road), storage functions, logistic and industrial functions, as well as satellite land terminals and dry ports. Figure $2 \nsucceq$ shows that virtually all port functions (at least in relation to containerized cargo), except for the transshipment and storage area located directly at the quay, can now be implemented using a system of well-connected external components of the port within a seamless logistics chain (Lu \& Chang, 2013). However, from the point of view of the port operation, its construction costs, operation and cargo handling time, it is a much less effective solution than a coherent spatial arrangement.

It happens that the operator of an existing port terminal wants to enlarge the terminal surface. Initially, one usually looks for the possibility of simple expansion of the terminal area with areas in the vicinity of an existing one. This was also the case with Deepwater Container Terminal in Gdańsk (construction of the T2 terminal at the border of the T1 terminal). However, if there are land shortages and the new terminal cannot physically adhere to the old one, it is necessary to create the so-called satellite terminal. The problem of satellite terminals has been widely discussed in the scientific literature since the beginning of the 1980s (Hayuth, 1981; Wiegmans, Masurel \& Nijkamp, 1999; Slack, 2007; Krośnicka, 2018), special attention being paid to the need of creating communication connections with the parent terminal (Daduna, 2011, p.387). Currently, transport between terminals is most often carried out using the shuttle transportation system, e.g. road trains (Krośnicka, 2016 p.152). Presumably, however, this solution will soon be replaced by the Automated Guided Vehicle convoys.

Two options ought to be mentioned among the currently existing solutions for the construction of satellite container terminals (Krośnicka, 2016, p.152), namely:

- the new container terminal is a land facility (dry short-range port), located near the parent terminal, usually at a distance of several hundred meters to several kilometers;

- a new deep-water container terminal is located near the port entrance. If it is built by an operator, who already has a container terminal inside the port area, the new terminal takes over 
the functions of the main center, while the old one performs auxiliary (satellite) functions. In this case, the transport of containers between the new and old terminal is usually carried out simultaneously by water (e.g. by barge, by container taxis) and by land.

\begin{tabular}{|c|c|c|c|c|c|}
\hline \multirow{2}{*}{ FORELAND } & PORT & \multicolumn{4}{|l|}{ HINTERLAND } \\
\hline & $\begin{array}{c}\text { function of } \\
\text { facilities bounded } \\
\text { functionally with } \\
\text { a terminal }\end{array}$ & $\begin{array}{l}\text { direct vicinity of } \\
\text { terminal } \\
\text { (up to } 5 \mathrm{~km} \text { ) }\end{array}$ & $\begin{array}{c}\text { port city } \\
\text { metropolis (up } \\
\text { to } 50 \mathrm{~km} \text { ) }\end{array}$ & $\begin{array}{l}\text { port city region } \\
\text { (up to } 150 \mathrm{~km} \text { ) }\end{array}$ & $\begin{array}{c}\text { further } \\
\text { hinterland (over } \\
300 \mathrm{~km} \text { ) }\end{array}$ \\
\hline \multirow{4}{*}{$\begin{array}{l}\text { as in ports' } \\
\text { hinterland } \\
\text { (vicinity of } \\
\text { terminal) }\end{array}$} & \multirow{4}{*}{$\begin{array}{l}\text { back-up facilities } \\
\text { (technical } \\
\text { support of a } \\
\text { terminal) }\end{array}$} & $\begin{array}{l}\text { external techno- } \\
\text { logical area }\end{array}$ & & & \\
\hline & & $\begin{array}{l}\text { parking for ter- } \\
\text { minal's transport } \\
\text { equipment }\end{array}$ & & & \\
\hline & & $\begin{array}{l}\text { terminal oil/gas } \\
\text { station }\end{array}$ & & & \\
\hline & & container depot & & & \\
\hline \multirow{4}{*}{$\begin{array}{l}\text { as in ports' } \\
\text { hinterland } \\
\text { (vicinity of } \\
\text { terminal) }\end{array}$} & \multirow[t]{4}{*}{$\begin{array}{l}\text { servicing area for } \\
\text { external } \\
\text { transportation }\end{array}$} & $\begin{array}{l}\text { gate's terminal } \\
\text { trucks' parking }\end{array}$ & extended & pre-gate & \\
\hline & & $\begin{array}{l}\text { gates' awaiting } \\
\text { truck lanes }\end{array}$ & \multirow{2}{*}{$\begin{array}{l}\text { close dry ports } \\
\text { and marshal- } \\
\text { ling railway } \\
\text { yards }\end{array}$} & & \\
\hline & & parking pre-gate & & & \\
\hline & & $\begin{array}{l}\text { external } \\
\text { terminals' } \\
\text { marshalling yard }\end{array}$ & & & \\
\hline \multirow{2}{*}{$\begin{array}{l}\text { as in ports' } \\
\text { hinterland } \\
\text { (vicinity of } \\
\text { terminal) }\end{array}$} & \multirow{2}{*}{$\begin{array}{l}\text { storage and } \\
\text { warehousing } \\
\text { areas and objects }\end{array}$} & $\begin{array}{l}\text { external storage } \\
\text { surfaces }\end{array}$ & & & \\
\hline & & carge freight & stations (CFS) & & \\
\hline \multirow{2}{*}{$\begin{array}{l}\text { as in ports' } \\
\text { hinterland } \\
\text { (vicinity of } \\
\text { terminal) }\end{array}$} & \multirow{2}{*}{$\begin{array}{l}\text { logistics and } \\
\text { industrial zones }\end{array}$} & distriparks & & & \\
\hline & & LC & logistic & and distribution & centers (LC) (LD) \\
\hline \multirow{2}{*}{$\begin{array}{l}\text { forelands' } \\
\text { satellite } \\
\text { terminals } \\
\text { (off-shore } \\
\text { terminals) }\end{array}$} & \multirow[t]{3}{*}{$\begin{array}{l}\text { inland and sea } \\
\text { satellite container } \\
\text { terminal }\end{array}$} & $\begin{array}{l}\text { inland satellite } \\
\text { terminal on close } \\
\text { ports' hinterland }\end{array}$ & & $\begin{array}{l}\text { dry ports of } \\
\text { medium range }\end{array}$ & $\begin{array}{l}\text { long-haul dry } \\
\text { ports }\end{array}$ \\
\hline & & new deep-water & & $\begin{array}{l}\text { dry ports of } \\
\text { medium range }\end{array}$ & $\begin{array}{l}\text { long-haul dry } \\
\text { ports (extended }\end{array}$ \\
\hline $\begin{array}{l}\text { satellite } \\
\text { terminals in } \\
\text { other ports } \\
\end{array}$ & & terminals & & $\begin{array}{l}\text { type) } \\
\text { type gate }\end{array}$ & gate type) \\
\hline \multicolumn{6}{|l|}{ Legend: } \\
\hline \multicolumn{6}{|c|}{$\begin{array}{l}\text { The character of collaboration of th } \\
\square \text { The external part of ports' cont } \\
\square \text { The object/area directly functic } \\
\square \text { The object/area collaborating } \\
\text { Iㅣㄴ Synchro-modal transportation }\end{array}$} \\
\hline
\end{tabular}

Figure 2. Classification of external objects/areas functionally bound with sea container terminals, based on the criteria of function, location and type of collaboration with the terminal Source: based on Krośnicka (2016, p.142). 
The second solution is associated with the expansion of the port function towards the sea waters, and therefore with direct consequences for planning of sea areas, related to the construction of artificial peninsulas, islands and other port constructions.

\section{Expansion of port structures towards the sea}

Starting with the 1990s on the forelands of ports located on the junctions of main shipping routes or on the forelands of large container terminal complexes, deep-water transit container terminals (so-called intermediate hubs, or transshipment ports) emerged (Krośnicka, 2016, p.170). They are most often built as greenfield projects on artificial islands, peninsulas or artificially added lands. Their function is to buffer the cargo mass from large container ships passing through the main shipping routes, and to mediate the distribution of cargo within the ports of a region. In the transit foreland terminals, such as Gioia Tauro (Italy), Algeciras (Spain), Tanjung Pelepas (Malaysia) the percentage share of containers in transit was over $80 \%$ in 2007, while in large deep-sea terminals situated within port cities such as Hong Kong (China), Rotterdam (Netherlands), Hamburg (Germany), cargo in transit accounted for about 40\% (Rodrigue \& Notteboom, 2010). Rodrigue and Notteboom (2010), and later on Monios and Wilmsmeier $(2012,2013)$ defined the phenomenon of moving the port functions outside the port area as regionalization, while referring both to the movement towards the hinterland and towards the foreland.

When Bird (1971) created the "anyport" model and the "downstream" rule, most port cities still had opportunities to develop down the river. Now, due to the land needs, as well as the desire to locate the terminal close to the port entrance, where sufficient depth is available and where approaching time is relatively short, it is often necessary to build new artificial lands outside the river channel, in the open sea (Krośnicka, 2010). Therefore, all modern ports tend to relocate some of the terminals to the new open sea locations. This process is especially visible in case of highly specialized oil terminals and refineries, bulk terminals and power plants, as well as container terminals.

Container terminals are currently most advanced in terms of search for external locations and the range of available spatial solutions. The new container terminals, or even complexes of terminals with their immediate facilities, might be situated (Fig. 3):

1. on artificial peninsulas built at the mouth of a river, e.g. Euromax, RWG, APM terminals at Maasvlakte 2 in Rotterdam (Netherlands), Tanjung Pelepas (Malaysia),

2. on artificial peninsulas built on the coast near the existing port, e.g. Deepwater Container Terminal in Gdańsk, the planned central port in Gdańsk, the planned container terminal in Gdynia (Poland),

3. on artificial peninsulas built on the coast in a new location away from the existing port, e.g. Jadeweser Terminal (Germany), located about $60 \mathrm{~km}$ north of the port of Bremen, port in Vuosaari (Finland) located $30 \mathrm{~km}$ east of the port of Helsinki, terminal Beverdonk (Belgium), located $50 \mathrm{~km}$ east of the port of Antwerp,

4. on islands connected to the mainland by a bridge structure, e.g. Yangshan container port (China).

The above solutions are listed in the order corresponding to the increasing level of complexity and difficulty of their implementation, hence the order, in which their construction would be considered. 


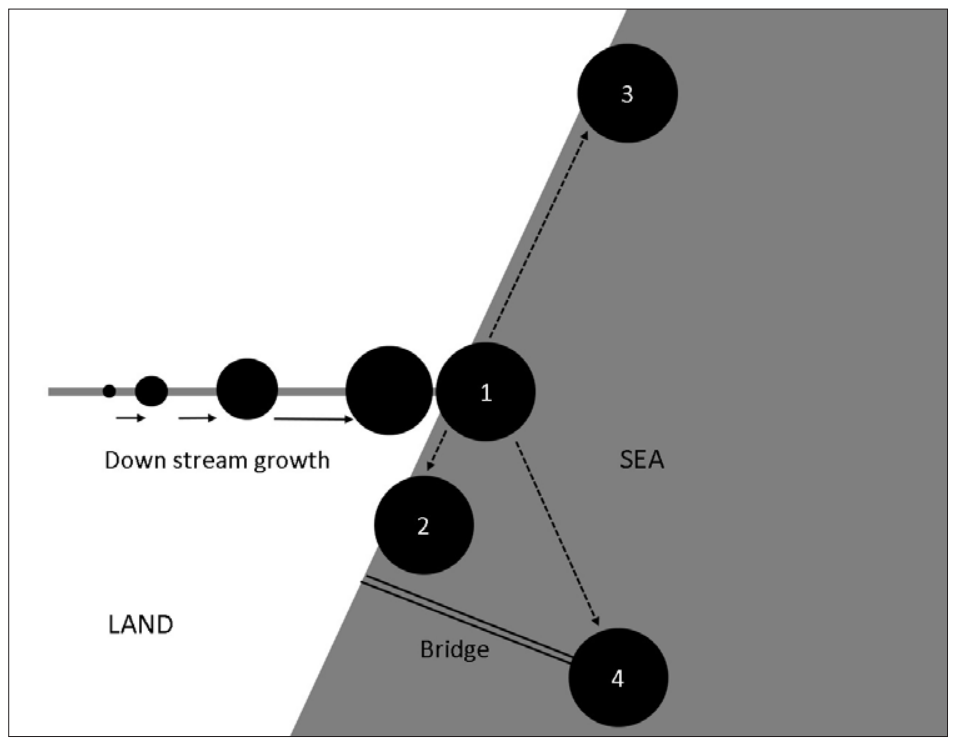

Figure 3. Evolution in the growth of ports and their terminals (description in the text) Source: own elaboration.

Until recently, off-shore solutions worked well in the case of handling liquid cargo, which could be pumped via pipelines from the terminal to the mainland. In case of off-shore oil and gas handling terminals an island was usually constructed as a platform on pylons. For some time, off-shore islands have been successfully used as space for container terminals (Wang \& Ducruet, 2012). They need, however, transport links (rail and road) with the land facilities in the form of multi-kilometer bridges (e.g. Yangshan in China, Kobe in Japan). These offshore solutions have a strong impact on development of maritime areas, as they are artificial islands, built in a process of land reclamation. The new land areas eliminate from other types of use not only the bottom space, but also the entire corresponding depth of the sea basin. The new ground structures must be additionally supplemented with bridge structures, connecting the island with mainland. The artificial island is totally changing the bottom configuration and local environmental conditions. Further, the bridge structures introduce restrictions for other users of sea, limiting the development possibilities on seawaters.

Apparently, the peninsular solutions seem to be slightly less invasive, because in theory they do not change the nature of the local environment (they remain in the coastal area). However, in this arrangement the configuration of the sea shore changes completely and the bottom in many areas of the port is strengthened and hardened. By introducing breakwaters and quays, the coastal processes are disturbed and the continuity of the coastal zone is interrupted. In fact, none of the above directions of port development is non-invasive, just as the construction of any infrastructure in the land area is not neutral for the environment. Therefore, the choice of a particular direction of port development should be carefully considered in the context of both local conditions and environmental relationships on a larger scale (e.g. bay or sea). There is no doubt that from the point of view of economic development and strategic interests of the port as well as the region and the country, new investments are necessary. It may be worth considering, 
however, as it is the case with road or other infrastructural investments, the introduction of principles of environmental compensation to the procedure of maritime spatial planning. These principles should be developed as a part of an interdisciplinary scientific discussion. At the same time, it is also worthwhile to review the effectiveness of the rules of planning and managing of the land areas of ports and their surroundings, so that areas originally intended for port functions could perform their functions, without restrictions due to the pressure of external activities. One should be aware of the shortages of available land reserves for port functions, as well as of the complex consequences that these deficiencies generate for sea basins.

\section{Conclusions}

Nowadays, ports should be planned as a complex system of infrastructure and facilities, both in foreland and in hinterland. Port infrastructures are, namely, expanding in land and sea directions at the same time. Not only the transshipment functions are now realized on the new surfaces, built on water, but there are also more and more of logistics and industrial activities, as well as activities connected with energy production located there. For maritime spatial planning the growing spatial demand from port functions regarding the sea signifies a growing pressure on maritime spaces.

Investments related to the expansion of ports into maritime areas allow for maintaining their competitiveness in relation to other ports, and thus the economic development of the port, its region and the country. However, due to the strong impact of these developments on the marine environment, they should now be considered in the interdisciplinary scientific discussion on how to introduce the principles of environmental compensation in maritime spatial planning. These principles should apply also to all other kinds of activities on the sea. At the same time, land reserves for port-transport and industrial functions on land should be sought so as to intervene in the marine environment as little as possible. This is only feasible in a situation of coordinating the development on the sea and land, made possible thanks to the implementation of Integrated coastal zone management (EC, 2014).

\section{References}

Bird, J. (1971). Seaports and Seaport Terminals. London: Hutchinson and Company.

Daduna, J.R. (2011). Importance of Hinterland Transport Networks for Operational Efficiency in Seaport Container Terminals. In J.W., Böse (Ed.). Handbook of Terminal Planning (pp. 381-397). New York: Springer-Verlag.

EC (2014). Directive 2014/89/EU of the European Parliament and of the Council of 23 July 2014 establishing a framework for maritime spatial planning.

Hayuth, Y. (1981). Containerisation and the load center concept. Economic Geography, 57(2), 160-176.

Krośnicka, K.A. (2010). The Impact of Sea-River Ports on Spatial Development of Cities. Logistics and Transport, 2(11), 39-44.

Krośnicka, K.A. (2014). Where does the container terminal really end? In A., Brandeis (Ed.). Water and Cities. Managing a Vital Relationship (pp. 1272-1279). Proceedings of the $50^{\text {th }}$ ISOCARP Congress Gdynia Urban Transformations: Cities and Water, Poland, 23-26 September 2014.

Krośnicka, K.A. (2016). Przestrzenne aspekty kształtowania i rozwoju morskich terminali kontenerowych. Gdańsk: Wydawnictwo Politechniki Gdańskiej.

Krośnicka, K.A. (2018). Spatial Evolution of the European Container Ports' System in Perspective of the Location Theory. SHS Web of Conferences, 58, 01016, pp. 12. https://www.shs-conferences.org/articles/shsconf/abs/2018/19/shsconf_globmar2018_01016/shsconf_globmar2018_01016.html 
Lu, J., \& Chang, Z. (2013). The Construction of Seamless Supply Chain Networks: The Development of dry Ports in China. In R., Bergqvist, G., Wilmsmeier \& K. Cullinane (Eds.). Dry Ports - A Global Perspective: Challenges and Developments in Serving Hinterlands (pp. 155-172). Farnham, Surrey, Burlington: Ashgate.

Monios, J., \& Wilmsmeier, G. (2012). Giving a direction to port regionalization. Transportation Research Part A, 46(10), 1551-1561. https://doi.org/10.1016/j.tra.2012.07.008

Monios, J., \& Wilmsmeier, G. (2013). The role of intermodal transport in port regionalization. Transport Policy, 30, 161-172. https://doi.org/10.1016/j.tranpol.2013.09.010

Rodrigue, J.-P., \& Notteboom, T. (2010). Foreland based regionalization: Integrating intermediate hubs with port hinterlands. Research in Transport Economics, 27(1), 19-29. https://doi.org/10.1016/j.retrec.2009.12.004

Schätzl, L. (1996). Wirtschaftsgeographie 1 - Theorie (6th Edition). Paderborn: UTB.

Slack, B. (2007). The terminalisation of seaports. In J., Wang, D., Olivier, T., Notteboom \& B., Slack (Eds.). Port, Cities and Global Supply Chains (pp. 41-50). Hampshire: Ashgate Publishing Limited.

Wang, C., \& Ducruet, C. (2012). New port development and global city making: emergence of the Shanghai-Yangshan multilayered gateway hub. Journal of Transport Geography, 25, 58-69. https://doi. org/10.1016/j.jtrangeo.2012.07.008

Wiegmans, B., Masurel, E., \& Nijkamp, P. (1999). Intermodal Freight Terminals: an Analysis of the Terminal Market. Transportation Planning and Technology, 23, 105-128. https://doi. org/10.1080/03081069908717643

Zaucha, J., \& Matczak, M. (2018). Role of Maritime Ports and Shipping in the Creation of the Economic Value of the Sea Areas. SHS Web of Conferences, 58, 01033, pp. 9. https://doi.org/10.1051/shsconf/20185801033 
